\title{
PENGARUH ENVIRONMENTAL PERFORMANCE DAN KOMPOSISI DEWAN KOMISARIS TERHADAP ENVIRONMENTAL DISCLOSURE
}

\author{
Muhammad Ahada \\ Unggul Purwohedi \\ Yunika Murdayanti \\ Universitas Negeri Jakarta
}

\begin{abstract}
This study aims to examine the influence of Environmental Performance and Board Composition on Environmental Disclosure. This study used two independent variables and the dependent variable, Environmental Performance and Board Composition as independent variables, and Environmental Disclosure as the dependent variable. Environmental Performance is measured by using level of PROPER, Board Composition is calculated by proportion of independen commisioner, and Environmental Disclosure is measured by using environmental disclosure GRI G3.

This study using secondary data, by using PROPER report and the annual report and also sustainability report that including the environmental information. Samples of this study consist of 24 company who join in PROPER and listed in Bursa Efek Indonesia during the period of 2011-2013.The data obtained by purposive sampling technique and using regression analysis method. Result from the model shows that: 1) Environmental Performance have a significant influence to Environmental Disclosure; 2) Board Composition have no significant influence to Environmental Disclosure 3) Simultaneus test, show that Environmental Performance and Board Composition have a significant influence to Environmental Disclosure.
\end{abstract}

Keywords: Environmental Performance, Board of Commisioners Composition, Environmental Disclosure.

\section{PENDAHULUAN}

Informasi yang terkandung di dalam laporan tersebut pada umumnya tidak hanya berisi mengenai informasi keuangan, tapi juga mengenai kegiatan sosial dan kegiatan lingkungan. Menurut Suratno (2006) dalam Sujarhanto dan Novita (2010), salah satu komponen yang ada dalam laporan tahunan perusahaan Jurnal IImiah Wahana Akuntansi adalah pengungkapan lingkungan (environmental disclosure), yaitu pengungkapan yang berkaitan dengan lingkungan hidup. Akan tetapi, hingga saat ini belum ada standar akuntansi keuangan yang mewajibkan perusahaan untuk melakukan pengungkapan lingkungan hidup (Sujarhanto dan Novita, 2010), sehingga membuat pengungkapan lingkungan menjadi tidak seragam antara 
satu perusahaan dengan perusahaan lainnya.

Tidak adanya peraturan yang mengatur secara ketat mengenai standar pengungkapan lingkungan menjadi satu permasalahan ketika dikaitkan dengan kondisi alam yang mengalami perubahan dan kerusakan yang diakibatkan oleh aktivitas perusahaan. Contoh kasus yang terjadi di tahun 2014, kerusakan lingkungan yang diakibatkan oleh aktivitas perusahaan-perusahaan tambang nikel di Sulawesi Tenggara yang menyisakan kawasan hutan gundul seluas 5000 hektar dengan perkiraan kerugian pemerintah daerah mencapai satu triliun rupiah (Abdi, 2014). Contoh lainnya, PT. Nusa Lontar Resources, yang mencemari air dan juga menimbulkan penyakit kulit (Bere, 2014), serta Kebakaran hutan di Riau terjadi hampir setiap tahun mulai dari tahun 1997 hingga 2014 (Kurniawan, 2014), merupakan satu kenyataan yang harus ditangani pemerintah.
Menurut undang-undang nomor 32 tahun 2009 pasal 67, setiap orang berkewajiban memelihara kelestarian fungsi lingkungan hidup serta mengendalikan pencemaran dan/atau kerusakan lingkungan hidup. Selanjutnya dalam pasal 68 huruf (a), menyatakan setiap orang yang melakukan usaha dan/atau kegiatan berkewajiban memberikan informasi yang benar dan akurat mengenai pengelolaan lingkungan hidup, dan apabila dilanggar akan dikenakan sanksi berupa hukuman penjara paling lama 1 (satu) tahun penjara dan denda paling banyak Rp1.000.000.000,00 (satu miliar rupiah).

Jika perusahaan melakukan pengungkapan lingkungan, seharusnya pemerintah dapat mengetahui dan mengantisipasi kerusakan lingkungan yang mungkin terjadi dengan membaca laporan pengungkapan lingkungan hidup perusahaan tersebut. Manfaat lainnya adalah memudahkan masyarakat yang 
mulai memiliki kesadaran lingkungan dalam memilih produk dari perusahaan yang ikut peduli lingkungan. Beberapa organisasi internasional telah menaruh perhatian khusus dalam hal kerusakan lingkungan, dan salah satunya adalah Global Reporting Initiative (GRI) yang mengeluarkan pedoman pelaporan pengungkapan lingkungan (Gladia dan Surya, 2013). Pedoman yang dikeluarkan GRI ini telah diadopsi oleh banyak perusahaan di dunia dalam mengungkapkan laporan lingkungan hidupnya.

Berdasarkan teori pengungkapan sukarela, hanya perusahaan dengan kinerja lingkungan (environmental performance) yang baik memiliki insentif untuk mengungkapkan pencapaiannya tersebut kepada stakeholder (Clarkson et al, 2010). Hal ini didasarkan demi meningkatkan citra perusahaan. Di Indonesia, dalam mengukur kinerja perusahaan, pemerintah membuat satu program yang dinamakan
Program Penilaian Peringkat Kinerja Perusahaan Dalam Pengelolaan Lingkungan Hidup (PROPER). Perusahaan yang telah terdaftar sebagai anggota PROPER ini akan diperiksa dan diberika nilai berupa warna emas, hijau, biru, merah dan hitam sesuai dengan usaha perusahaan tersebut dalam menjaga lingkungan hidup. Penelitian yang terkait pengaruh kinerja lingkungan terhadap pengungkapan lingkungan telah dilakukan oleh Gladia dan Surya (2013), menunjukkan hubungan yang positif antara kinerja lingkungan terhadap pengungkapan lingkungan. Hal ini didasarkan atas teori legitimasi yang menyatakan perusahaan berkepentingan untuk menjaga hubungan baik dengan masyarakat.

Hasil yang berbeda ditunjukkan oleh Clarkson et al (2010), yang menyatakan terdapat hubungan negatif antara environmental performance terhadap environmental disclosure yang didasarkan pada teori socio-political. Penelitian Jurnal IImiah Wahana Akuntansi 
tersebut menyimpulkan bahwa perusahaan dengan kinerja lingkungan rendah justru lebih memiliki dorongan untuk membuat pengungkapan lingkungan agar keberadaannya dapat diterima masyarakat.

Pengungkapan lingkungan memiliki keterkaitan erat dengan Corporate Social Responsibility (CSR). CSR juga memiliki keterkaitan dengan komposisi dewan komisaris yang ada di dalam satu perusahaan, walaupun tidak banyak pihak yang menyadarinya (Ibrahim, 2003 dalam Uwigbe et al, 2010). Peran dewan komisaris sebagai pengawas dari manajemen, memastikan laporan yang dibuat manajemen sesuai dengan tuntutan stakeholder. Dan komisaris yang berasal dari luar eksekutif perusahaan berperan penting dalam pandangannya mengenai tuntutan stakeholder eksternal.

Penelitian yang meneliti mengenai pengaruh dewan komisaris independen terhadap pengungkapan lingkungan telah dilakukan oleh Uwigbe et al (2011), menyatakan hasil bahwa terdapat hubungan positif antara dewan komisaris independen terhadap pengungkapan lingkungan hidup. Hal ini dikarenakan keberadaan dewan komisaris independen yang berasal dari luar perusahaan dapat merepresentasikan pandangan dari stakeholdereksternal yang membutuhkan informasi dari pengungkapan lingkungan. Hasil yang sama juga dijelaskan dalam penelitian Suharjanto dan Novita (2010).

Hasil yang berbeda ditunjukkan oleh Effendi et al (2011), yang menyatakan tidak ada hubungan antara dewan komisaris independen dengan pengungkapan lingkungan perusahaan, dewan komisaris independen dianggap tidak memiliki pengaruh dalam pengambilan keputusan karena tidak terkait langsung dalam aktivitas atau operasi sehari-hari perusahaan.

Dari uraian diatas alasan pemilihan tema penelitian ini adalah masih terdapat perbedaan hasil antara penelitian satu Jurnal IImiah Wahana Akuntansi 
dengan penelitian lainnya (research gap),

serta menurut pengamatan peneliti,

penelitian ini masih sedikit dilakukan di

Indonesia. Oleh karena itu, penelitian ini

menguji pengaruh environmental

performance terhadap environmental

disclosure dan pengaruh komposisi dewan

komisaris terhadap environmental

disclosure.

KERANGKA

PERUMUSAN

TEORITIK DAN

HIPOTESIS

lingkungan yang dilakukan perusahaan terkait lingkungan, sehingga lingkungan hidup dapat tetap terjaga. Hal ini mengingat perusahaan juga turut berperan serta dalam kerusakan lingkungan sebagai akibat dari aktivitas yang dilakukannya juga menghasilkan sisa ataupun limbah. Untuk mengukur pengungkapan lingkungan salah satunya dapat menggunakan indeks pengungkapan lingkungan dari pedoman keberlangsungan yang dikeluarkan GRI, yang terdiri atas 9 aspek yaitu: material, energi, air, biodiversitas, emisi, produk dan jasa, kepatuhan, transportasi, menyeluruh.

\section{Environmental Performance}

Environmental performance

merupakan usaha-usaha yang dilakukan perusahaan dalam menjaga kelestarian lingkungan, terutama yang berkaitan dengan kegiatan atau aktivitas perusahaan itu sendiri. Usaha-usaha tersebut dapat berupa penggunaan teknologi pengurang limbah, kegiatan reboisasi, pengurangan Jurnal IImiah Wahana Akuntansi 
penggunaan air dan masih banyak lagi. Perusahaan yang memiliki kinerja lingkungan yang baik, seharusnya memiliki dorongan untuk mengungkapkan pencapaiannya tersebut kepada publik. Kinerja lingkungan yang baik merupakan satu prestasi tersendiri yang dapat mengangkat citra perusahaan di mata masyarakat, bahwa perusahaan tersebut peduli terhadap lingkungan hidup. Di Indonesia, pemerintah melalui Kementrian Lingkungan Hidup mengeluarkan program PROPER yang dapat digunakan sebagai tolak ukur kinerja perusahaan.

\section{Komposisi Dewan Komisaris}

Dewan komisaris memiliki fungsi pengawasan di dalam perusahaan untuk memastikan aktivitas yang dilakukan manajer telah baik dan benar. Dewan komisaris yang juga terdiri dari komisaris independen diharapkan mampu memberikan tekanan kepada pihak manajer untuk melakukan pengungkapan lingkungan yang merupakan kepentingan dari stakeholder, terutamastakeholder eksternal.

\section{Perumusan Hipotesis}

\section{a. Pengaruh Environmental Performance terhadap Environmental Disclosure}

Menurut teori legitimasi (Suwaldiman, 2009), perusahaan melakukan kontrak sosial dengan masyarakat agar keberadaan mereka diakui dan mendapat legitimasi dari masyarakat. Penelitian Gladia dan Surya (2011), menunjukkan hubungan yang positif antara kinerja lingkungan terhadap pengungkapan lingkungan, hal ini sejalan dengan teori legitimasi. Sedangkan penelitian yang dilakukan Clarkson et al (2010) menyatakan terdapat hubungan negatif antara environmental performance terhadap environmental disclosure yang didasarkan pada teori socio-political. Penelitian tersebut menyimpulkan bahwa perusahaan dengan kinerja lingkungan rendah justru lebih memiliki dorongan untuk membuat pengungkapan lingkungan Jurnal IImiah Wahana Akuntansi 
agar keberadaannya dapat diterima masyarakat. Dari uraian diatas, maka hipotesis pertama dalam penelitian ini adalah:

$\mathrm{H}_{1}$ : Environmental Performance memiliki pengaruh terhadap Environmental Disclosure.

\section{b. Pengaruh Komposisi Dewan Komisaris terhadap Environmental Disclosure}

Penelitian sebelumnya membuktikan ada pengaruh positif dari peran dewan komisaris terhadap pengungkapan lingkungan. Penelitian Suhardjanto dan Novita (2010) dan penelitian Uwuigbe et al (2011), menyatakan hasil positif dalam pengaruh komposisi dewan komisaris terhadap pengungkapan lingkungan. Namun penelitian Effendi et al (2011) menyatakan hasil yang berbeda, yakni tidak ada pengaruh komisaris independen terhadap pengungkapan lingkungan perusahaan. Dari uraian diatas, maka hipotesis pertama dalam penelitian ini adalah:
$\mathrm{H}_{2}$ : Komposisi dewan komisaris memiliki pengaruh terhadap Environmental Disclosure.

\section{METODOLOGI PENELITIAN}

\section{Objek dan Ruang Lingkup Penelitian}

Penelitian ini menggunakan data sekunder berupa laporan hasil penilaian PROPER dan laporan tahunan serta laporan keberlanjutan perusahaan anggota PROPER yang terdaftar di BEI untuk periode tahun 2011 - 2013. Sumber data diperoleh dari laporan hasil penilaian PROPER diwebsite Kementerian Lingkungan Hidup (http://www.proper.menlh.go.id) dan laporan keuangan tahunan perusahaan selama periode 2011 - 2013 yang di sajikan di websitehttp://www.idx.co.id.

\section{Populasi dan Sampling}

Populasi yang digunakan dalam penelitian ini adalah perusahaanperusahaan anggota PROPER yang sudah melakukan go public ataupun yang telah 
terdaftar di BEI.Adapun sampel yang digunakan dalam penelitian ini dipilih menggunakan metode purposive sampling, dengan kriteria sebagai berikut:

a. Perusahaan anggota PROPER 20112013.

b. Perusahaan merupakan perusahaan yang telah go public tidak delisting dari BEI selama tahun amatan.

c. Mempublikasikan annual report secara konsisten dan lengkap, atau dilengkapi dengan sustainability report yang memuat informasi environmental disclosure.

3. Operasionalisasi Variabel Penelitian

\section{a. Environmental Disclosure}

Pengukuran environmental disclosure menggunakan skor pengungkapan lingkungan pada annual report dengan indeks GRI. Penggunaan indeks GRI dalam menghitung pengungkapan lingkungan sama seperti penelitian yang dilakukan Effendi et al (2011), yaitu dengan memberikan nilai 1 atas setiap pengungkapan yang sesuai dengan indeks 30 poin lingkungan GRI. Selanjutnya nilai tersebut dijumlahkan dan di bandingkan dengan total 30 poin pengungkapan lingkungan GRI, cara penghitungannya:

$\frac{\text { Skor pengungkapan lingkungan perusahaan }}{\text { Total seluruh pengungkapan lingkungan GRI (30 poin) }} \times 100 \%$

\section{b. Environmental Performance}

Pada penelitian ini pengukuran Environmental Performance menggunakan hasil penilaian PROPER yang dilakukan Kementrian Lingkungan Hidup, seperti yang dilakukan Gladia dan Surya (2013). Hasil penilaian PROPER adalah berupa warna yang menunjukkan tingkat kinerja lingkungan perusahaan, yaitu dimulai dari emas, hijau, biru, merah dan hitam. Pada penelitian yang dilakukan Gladia dan Surya (2013). Peringkat warna PROPER diproksikan dengan nilai, sedangkan untuk memperoleh rasionya dilakukan beberapa perhitungan lebih lanjut. 
Berdasarkan tabel indikator peringkat PROPER dari Kementrian Lingkungan Hidup dalam Handayani (2010), tingkat kinerja lingkungan hidup perusahaan terbagi 4, yaitu:

(1) Melakukan usaha pengelolaan lingkungan hidup, namun masih kurang dari persyaratan perundangundangan. $($ Merah $=1)$

(2) Melakukan usaha pengelolaan lingkungan hidup sesuai dengan perundang-undangan, namun belum memenuhi batas beyond compliance. $($ Biru $=2)$

(3) Melakukan usaha pengelolaan lingkungan dan memenuhi batasbeyond compliance, namun belum terlihat kemajuannya. (Hijau $=3)$

(4) Melakukan usaha pengelolaan lingkungan dan memenuhi batas beyond compliance selama dua tahun berturut - turut dan terdapat kemajuan. $($ Emas $=4)$
Peringkat Hitam tidak memiliki nilai (0), karena peringkat hitam berarti perusahaan tersebut tidak melakukan upaya penyelamatan lingkungan hidup, bahkan dengan sengaja melakukan pembiaran atas kerusakan lingkungan yang terjadi akibat operasional perusahaan. Selanjutnya, untuk memperoleh rasio dari peringkat PROPER, maka menggunakan rumus:

$\frac{\text { Tingkat kinerja lingkungan hidup perusahaan }}{\text { Tingkat maksimum kinerja lingkungan hidup (4) }} \times 100 \%$

\section{c. Komposisi Dewan Komisaris}

Pada penelitian ini profitabilitas komposisi dewan komisaris di proksikan dengan perbandingan antara porsi komisaris independen dengan total seluruh anggota dewan komisaris (Effendi et al, 2011). Adapun cara rumusnya adalah sebagai berikut:

$$
\frac{\sum \text { Komisaris Independen }}{\sum \text { Dewan Komisaris }} \times 100 \%
$$

\section{Teknik Analisis}

Penelitian ini menggunakan teknik analisis regresi berganda yang digunakan 
untuk mengidentifikasi seberapa kuat hubungan dan arah antara variabel dependen dengan variabel independen (Ghozali, 2011), yaitu pengaruh Environmental Performance dan Komposisi Dewan Komisaris terhadap Environmental Disclosure.

Persamaan umum regresi berganda yang digunakan dalam penelitian ini yaitu:

$\mathrm{Y}=\mathrm{a}+\mathrm{b}_{1} \mathrm{X}_{1}+\mathrm{b}_{2} \mathrm{X}_{2}+\varepsilon \ldots \ldots \ldots \ldots$

Keterangan:

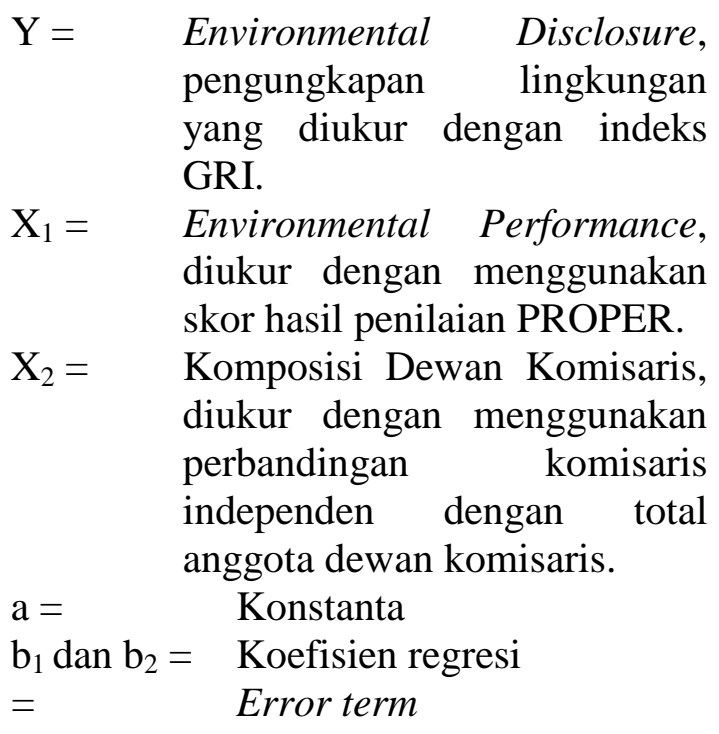

\section{HASIL PENELITIAN DAN PEMBAHASAN}

\section{Deskripsi Statistik Data}

Jumlah perusahaan yang ada dalam populasi perusahaan - perusahaan yang Jurnal IImiah Wahana Akuntansi menjadi anggota PROPER dan terdaftar di Bursa Efek Indonesia (BEI) dalam tahun 2011-2013 adalah 49 perusahaan. Setelah dilakukan penyeleksian sampel, diperoleh 24 perusahaan yang termasuk dalam kriteria sampel, yaitu perusahaan yang terdaftar sebagai anggota PROPER dan terdaftar di BEI serta mempublikasi laporan keuangan yang mengandung informasi lingkungan pada tahun 2011 hingga 2013 ataupun dalam bentuk laporan keberlanjutan

\section{Tabel 1}

\section{Hasil Uji Statistik Deskriptif}

Descriptive Statistics

\begin{tabular}{|l|r|r|r|r|r|}
\hline & $\mathrm{N}$ & Minimum & Maximum & Mean & Std. Deviation \\
\hline & 72 & 3,33 & 100,00 & 31,0651 & 33,42140 \\
ED & 72 & 25,00 & 100,00 & 57,4306 & 16,04596 \\
EP & 72 & 30,00 & 80,00 & 42,7738 & 11,00710 \\
KI & & & & \\
Valid N \\
(listwise)
\end{tabular}

Nilai terendah dari ED adalah 3,33. Angka ini mencerminkan bahwa informasi yang diungkapkan oleh perusahaan hanya $3,33 \%$ dari keseluruhan informasi lingkungan atau hanya satu dari 30 kriteria yang dipersyaratkan GRI G3 bagian 
lingkungan. Nilai tertinggi dari ED adalah 100, yang bermakna pengungkapan lingkungan yang dilakukan perusahaan telah mencantumkan keseluruhan informasi lingkungan atau memenuhi semua kriteria lingkungan GRI G3. Nilai pengungkapan lingkungan yang rendah masih mendominasi, terbukti dari nilai rata - rata ED yang hanya 31,0651. Angka ini menunjukkan bahwa secara rata - rata perusahaan perusahaan di Indonesia yang menjadi anggota PROPER dan terdaftar di BEI serta mengungkapkan informasi lingkungan di annual report ataupun sustainability report, hanya mengungkapkan 31,06 \% dari keseluruhan informasi lingkungan yang diungkapkan kepada masyarakat atau dengan kata lain hanya mengungkapkan 9 poin dari 30 kriteria pengungkapan lingkungan yang dipersyaratkan GRI G3.

Nilai terendah EP adalah 25 yang bermakna tingkat PROPER yang berhasil dicapai perusahaan tersebut hanya $25 \%$ dari nilai indeks PROPER secara keseluruhan atau hanya masuk kriteria indeks PROPER merah. Nilai EP tertinggi adalah 100 yang artinya perusahaan tersebut melakukan usaha kegiatan lingkungan yang menurut pemerintah usahanya tersebut telah memenuhi semua kriteria kegiatan penjagaan dan penyelamatan lingkungan bahkan melampaui dari aspek yang dipersyaratkan pemerintah. Secara rata - rata nilai EP adalah 57,4306 yang merupakan nilai yang cukup baik. Hal ini dikarenakan untuk memenuhi kriteria ketaatan yang baik atau mencapai peringkat biru dalam PROPER.

Nilai terendah dari KI adalah 30 yang bermakna jumlah komisaris independen dari keseluruhan anggota dewan komisaris hanya 30\%. Hal ini menunjukkan jumlah komisaris independen yang sedikit di bandingkan dengan jumlah keseluruhan dewan komisaris. Nilai tertinggi dari KI adalah 80 yang bermakna anggota komisaris independen berjumlah $80 \%$ dari total keseluruhan anggota dewan komisaris. Secara keseluruhan perbandingan komisaris independen dan dewan komisaris di perusahaan - perusahaan Indonesia cukup berimbang dan telah memenuhi peraturan persyaratan jumlah anggota komisaris independen, hal ini terlihat dari nilai rata - rata yang hampir mencapai 50\% yakni 42,7738. Menurut peraturan pemerintah dalam Surat Edaran Kepala Bapepam No.SE-03/PM/2000 dan peraturan pasar modal menentukan bahwa perusahaan terbuka harus memiliki paling tidak $30 \%$ anggota komisaris independen Jurnal IImiah Wahana Akuntansi 
dalam keseluruhan anggota dewan komisaris.

Tabel 2

\section{Hasil Uji Kolmogorof-Smirnov}

One-Sample Kolmogorov-Smirnov Test

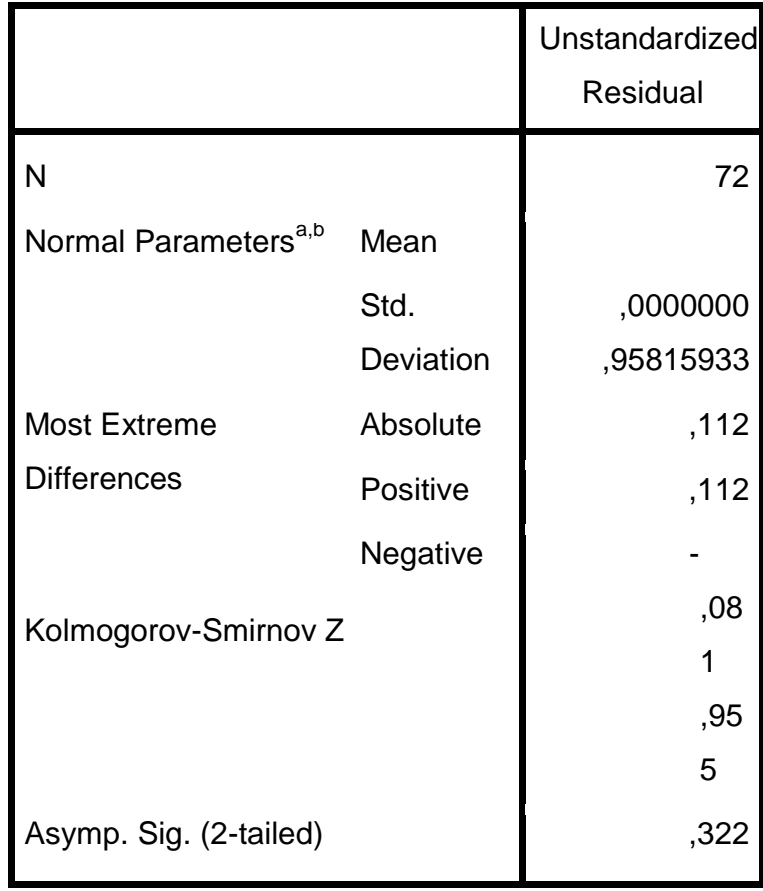

a. Test distribution is Normal.

b. Calculated from data.

Sumber: Diolah oleh penulis dengan spss 19(2014)

Pada uji normalitas yang dilakukan pada penelitian ini dilakukan pengujian analisis grafik P-P Plot dan analisis statistik One - Sample Kolomogorov Jurnal IImiah Wahana Akuntansi
Smirnov, namun pada kedua uji tersebut menampilkan hasil bahwa data tidak terdistribusi secara normal. Untuk mengatasi hal tersebut, dilakukanlah transformasi data agar menjadi normal (Ghazali, 2011). Setelah dilakukan transformasi data ke bentuk Log natural, maka dilakukan uji analisis grafik P-P Plot dan analisis One - Sample Kolomogorov Smirnov kembali. Tingkat kenormalan yang diuji dengan Kolmogorov-Smirnov Z menunjukan nilai Kolmogorov-Smirnov Z sebesar 0,955 dan Asymp. Sig. Sebesar 0,322 yang lebih besar dari 0,05 . Hal ini berarti data berdistribusi normal.

Tabel 3

\section{Hasil Uji Multikolinieritas}

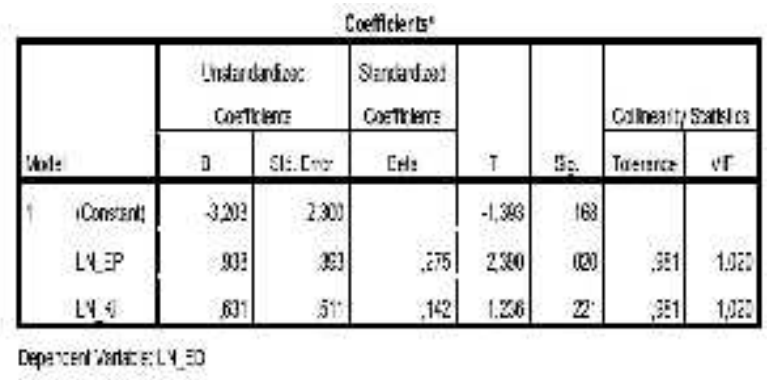

Suatu model regresi dikatakan tidak memiliki kecenderungan adanya gejala multikolinearitas adalah jika memiliki tolerance value yang lebih besar dari 0.10 dan nilai VIF yang lebih kecil dari 10. Berdasarkan hasil tabel 4.4 menunjukkan bahwa nilai Tolerance semua variabel lebih besar dari 0,10 $\left(\mathrm{X}_{1}=0,981\right.$ dan $\mathrm{X}_{2}=$ 0,981), serta nilai VIF lebih kecil dari 
$10,00\left(X_{1}=1,020\right.$ dan $\left.X_{2}=1,020\right)$.

Dengan demikian, hasil pengujian model regresi ini dapat disimpulkan bahwa tidak terjadiMultikolinearitas dalam variabel penelitian ini.

\section{Tabel 4}

\section{Hasil Uji Durbin-Watson}

\begin{tabular}{|c|c|c|c|c|c|c|c|c|}
\hline \multicolumn{9}{|c|}{ Model Summary ${ }^{b}$} \\
\hline \multicolumn{3}{|c|}{ Model } & $\begin{array}{l}\text { Unstanda } \\
\text { Coeffici } \\
\text { B }\end{array}$ & $\begin{array}{c}\text { ardized } \\
\text { ients } \\
\text { Std. } \\
\text { Error }\end{array}$ & $\begin{array}{l}\text { Stan } \\
\text { Coe }\end{array}$ & $\begin{array}{l}\text { Idardized } \\
\text { efficients } \\
\text { Beta }\end{array}$ & $\mathrm{t}$ & Sig. \\
\hline \multirow[t]{3}{*}{1} & \multicolumn{2}{|c|}{ (Constant) } &,- 680 & 1,324 & & &,- 514 & ,609 \\
\hline & \multicolumn{2}{|c|}{ LN_EP } &, 014 & ,226 & & ,008 & ,064 & ,949 \\
\hline & \multicolumn{2}{|c|}{ LN_KI } & ,374 & ,294 & & ,153 & 1,272 & 207 \\
\hline Model & $\mathrm{R}$ & $\begin{array}{l}\mathrm{R} \\
\text { Square }\end{array}$ & $\begin{array}{c}\text { Adjuste } \\
\mathrm{R} \\
\text { Square }\end{array}$ & \begin{tabular}{l|l} 
edd. & Stro \\
Erro & \\
the \\
Estir
\end{tabular} & mate & $\begin{array}{l}\text { Durbin- } \\
\text { Watson }\end{array}$ & & \\
\hline 1 &, $326^{a}$ & ,106 & ,08 & 81 & 7195 & 1,831 & & \\
\hline
\end{tabular}

Sumber: Diolah oleh penulis dengan spss 19(2014)

Nilai DW dari hasil uji akan dibandingkan dengan nilai tabel t signifikansi 5\%, jumlah sampel (n) 72 dan jumlah variabel independen $2(\mathrm{~K}=2)$, m ka diperoleh nilai $\mathrm{du}=1,6751, \mathrm{dL}=1,561$ Mlodel Nilai DW dibandingkan dengan nilai diu dan nilai 4-du(2,3249), yakni

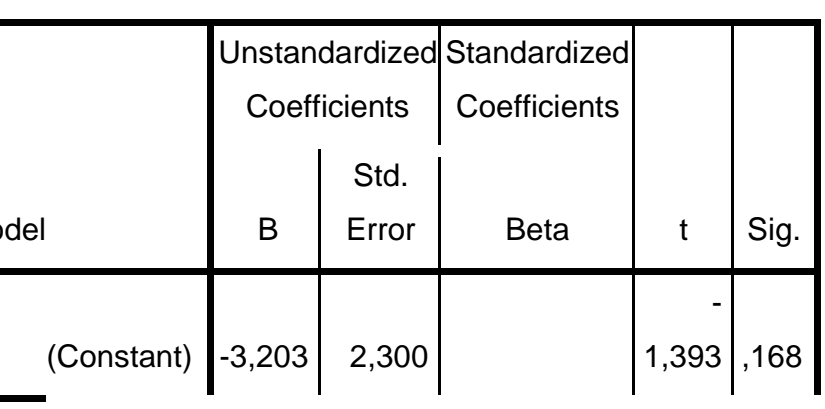
Jurnal IImiah Wahana Akuntansi 


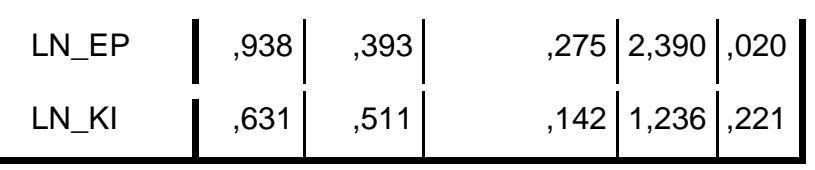

a. Dependent Variable: LN_ED

Sumber: Diolah oleh penulis dengan spss 19(2014)

Berdasarkan hasil analisis regresi komposisi dewan komisaris $\left(\mathrm{X}_{2}\right)$ sebesar 0,631, artinya jika variabel independen lain nilainya tetap dan komposisi dewan komisaris mengalami kenaikan 1\%, maka nilai environmental disclosure (Y) hanya akan mengalami peningkatan sebesar 0,631 atau $63,1 \%$.

\begin{tabular}{|c|c|c|c|c|c|c|}
\hline \multicolumn{2}{|c|}{ Model } & \multicolumn{2}{|c|}{$\begin{array}{l}\text { Unstandardized } \\
\text { Coefficients } \\
\begin{array}{l|c|}\text { B } & \text { Std. } \\
\text { B } & \text { Error }\end{array}\end{array}$} & $\begin{array}{c}\text { Standardized } \\
\text { Coefficients } \\
\text { Beta }\end{array}$ & $\mathrm{t}$ & Sig. \\
\hline \multirow[t]{3}{*}{1} & (Constant) & $-3,203$ & 2,300 & & $-1,393$ & 168 \\
\hline & LN_EP & ,938 & ,393 & ,275 & 2,390 & ,020 \\
\hline & LN_KI & ,631 &, 511 &, 142 & 1,236 & ,221 \\
\hline
\end{tabular}

yang disajikan dalam tabel, dapat

dituliskan model regresi sebagai berikut:

$$
\mathrm{Y}=-\mathbf{3 , 2 0 3}+\mathbf{0 , 9 3 8 X 1}+\mathbf{0 , 6 3 1 X 2}+\mathrm{e}
$$

Persamaan regresi di atas dapat dijelaskan sebagai berikut:

Konstanta sebesar -3,203, artinya jika environmental perfomance (X1) dan komposisi dewan komisaris (X2) nilainya adalah 0, maka environmental disclosure (Y) nilai rasionya adalah $-3,203$. Koefisien regresi variabel environmental performance $\left(\mathrm{X}_{1}\right)$ sebesar 0,938 , artinya jika variabel independen lain nilainya tetap dan environmental performance mengalami kenaikan 1\%, maka penilaian environmental disclosure (Y) akan mengalami peningkatan sebesar 0,938 atau 93,8\%. Koefisien regresi variabel Jurnal IImiah Wahana Akuntansi

\section{Tabel 7}

\section{Hasil Uji t}

\section{Coefficients $^{\mathrm{a}}$}

Dependent Variable: LN_ED

Sumber: Diolah oleh penulis dengan spss 19(2014)

EP dengan nilai probabilitas 0,05 memiliki $\mathrm{t}$ hitung $=2,390$ dan $\mathrm{t}$ tabel $=$ 1,99495; sehingga $\mathrm{t}$ hitung $>\mathrm{t}$ tabel dapat disimpulkan bahwa environmental performance memiliki kontribusi terhadap environmental disclosure. Nilai t hitung yang positif menunjukkan bahwa variabel environmental performance mempunyai hubungan searah terhadap environmental disclosure. Nilai signifikan $=0,020<0,05$ maka hipotesis $1\left(\mathrm{H}_{1}\right)$ diterima. Sehingga dapat disimpulkan environmental performance berpengaruh positif 
signifikan terhadap environmental disclosure.

Tabel 9

KI dengan nilai probabilitas 0,05 memiliki $\mathrm{t}$ hitung $=1,236$ dan $\mathrm{t}$ tabel $=$ 1,99495; sehingga $t$ hitung $<\mathrm{t}$ tabel dapat disimpulkan bahwa komposisi dewan komisaris tidak memiliki kontribusi terhadap environmental disclosure. Nilai signifikan $=0,221>0,05$ maka hipotesis 2 $\left(\mathrm{H}_{2}\right)$ ditolak. Sehingga dapat disimpulkan komposisi dewan komisaris tidak berpengaruh secara signifikan terhadap environmental disclosure.

\section{Tabel 8}

\section{Hasil Uji F}

ANOVA $^{b}$

a. Predictors: (Constant), LN_KI, LN_EP

b. Dependent Variable: LN_ED

Sumber: Diolah oleh penulis dengan spss 19(2014)

Dari output pada model yang kedua terlihat bahwa F hitung $=4,108$ dan F tabel $=3,13$; dengan probabilitas 0,05 , sehingga $\mathrm{F}$ hitung $>\mathrm{F}$ tabel dan tingkat signifikansi $0,021<0,05$ maka dapat dinyatakan secara simultan variabel environmental performance $\left(\mathrm{X}_{1}\right)$ dan komposisi dewan komisaris $\left(\mathrm{X}_{2}\right)$ berpengaruh signifikan terhadap environmental disclosure (Y). Jurnal IImiah Wahana Akuntansi 
2. Pembahasan

a. Pengaruh

Performance

Environmental

Terhadap

\section{Environmental Disclosure}

Hipotesis pertama menyatakan terdapat pengaruh environmental performance terhadap environmental disclosure. Hipotesis pertama diterima berdasarkan hasil pengujian hipotesis secara parsial yang menunjukkan signifikansi 0,020 lebih kecil dari 0,05. Hal ini membuktikan bahwa environmental performance mempengaruhi environmental disclosure.

Hasil penelitian ini konsisten dengan penelitian Gladia dan Surya (2013) yang menyatakan bahwa perusahaan yang memiliki kinerja lingkungan yang tinggi akan menginformasikan usaha ataupun prestasinya tersebut seluas mungkin demi mencapai legitimasi dari masyarakat. Lebih lanjut, dalam teori legitimasi menyatakan bahwa perusahaan dalam melakukan satu kegiatan tertentu, termasuk pengungkapan informasi, karena didasari kebutuhan untuk mendapatkan legitimasi dari masyarakat (Suwaldiman, 2009). Perusahaan melakukan pengungkapan informasi sebagai satu strategi untuk memenuhi harapan masyarakat demi menjaga hubungan baik.
Apabila perusahaan gagal memenuhi harapan tersebut, maka eksistensi perusahaan di tengah masyarakat menjadi terancam. Menurut Drucker (1973) dalam Harahap (2011), tidak ada perusahaan yang dapat berdiri sendiri ataupun terpisah dari kepentingan masyarakat, sehingga perusahaan dikatakan baik jika baik bagi masyarakat. Perusahaan yang melakukan kegiatan lingkungan yang baik akan memiliki dorongan yang kuat untuk melakukan pengungkapan kepada publik karena hal itu akan menjadi satu insentif tersendiri bagi perusahaan. Keberadaan perusahaan oleh masyarakat akan lebih diterima dan bahkan produk-produknya akan lebih disukai masyarakat karena meningkatnya kepedulian masyarakat terhadap lingkungan.

Sebaliknya, perusahaan yang memiliki kinerja lingkungan yang rendah, tidak memiliki dorongan untuk melakukan pengungkapan informasi lingkungan secara rinci. Hal ini dikarenakan perusahaan tidak ingin kinerja lingkungannya yang masih rendah, diketahui oleh masyarakat luas dan mengurangi nilai atau pun citra perusahaan. Perusahaan baru akan melakukan pengungkapan informasi yang lebih luas pada tahun berikutnya, jika telah memiliki kinerja ataupun prestasi Jurnal IImiah Wahana Akuntansi 
lingkungan yang dinilai cukup baik dan dianggap dapat mengangkat citra atau nilai perusahaan.

\section{b. Pengaruh Komposisi Dewan Komisaris Terhadap}

\section{Environmental Disclosure}

Hipotesis kedua menyatakan Komposisi dewan komisaris memiliki pengaruh terhadap Environmental Disclosure. Hasil pengujian hipotesis secara parsial menunjukkan hasil 0,221 lebih besar dari 0,05. Hal ini menunjukkan bahwa hipotesis kedua tidak dapat diterima atau dengan kata lain komposisi dewan komisaris tidak memiliki pengaruh terhadap pengungkapan lingkungan perusahaan.

Hasil penelitian ini sejalan dengan hasil penelitian Efendi et al (2011) yang menyatakan komisaris independen tidak memiliki pengaruh terhadap pengungkapan lingkungan perusahaan. Hal ini disebabkan oleh peran komisaris independen yang tidak secara langsung menjalankan kegiatan perusahaan sehingga tidak begitu memiliki pengaruh dalam pengambilan keputusan, misalnya dalam pembuatan pengungkapan lingkungan. Sifat komisaris independen yang seharusnya lebih kredibel dan tidak memiliki kepentingan layaknya komisaris non - independen, belum cukup kuat untuk mempengaruhi keputusan dalam pembuatan pengungkapan lingkungan.

Ketidakmampuan

komisaris independen dalam mempengaruhi pengambilan keputusan terkait pengungkapan informasi lingkungan perusahaan ini, dapat dipengaruhi oleh beberapa faktor, antara lain rangkap jabatan, latar belakang pendidikan dan latar belakang pekerjaan komisaris independen. Komisaris independen dalam beberapa perusahaan rata-rata merangkap sebagai komisaris independen ataupun direktur di perusahaan lain. Hampir semua perusahaan yang ada di dalam sampel penelitian ini, sebagian komisaris independennya merupakan orang - orang yang memiliki rangkap jabatan, baik itu sebagai komisaris, direktur ataupun jabatan di pemerintahan. Adanya rangkap jabatan dapat menyebabkan seorang komisaris independen tidak fokus mengawasi satu perusahaan yang menjadi tanggung jawabnya.

Latar belakang pendidikan komisaris independen rata-rata adalah sarjana ekonomi dan Hukum, bukan pendidikan yang berkaitan langsung dengan lingkungan hidup, misalnya kehutanan, sehingga dapat mempengaruhi kepedulian mengenai lingkungan hidup. Selain itu, Jurnal IImiah Wahana Akuntansi 
menurut pengamatan peneliti, tidak ada anggota komisaris independen yang berasal dari lembaga swadaya masyarakat yang memang memiliki kepedulian tinggi di dalam lingkungan hidup.

\section{c. Pengaruh \\ Environmental \\ Performance Dan Komposisi \\ Dewan Komisaris Terhadap \\ Environmental Disclosure}

Berdasarkan uji $\mathrm{F}$ atau uji simultan, variabel-variabel independen (environmental performance dan komposisi dewan komisaris) diujikan secara bersamaan, dan didapat hasil berpengaruh signifikan terhadap environmental disclosure. Nilai signifikansinya 0,021 yang lebih kecil dari 0,05 menunjukkan adanya pengaruh signifikan positif dari kedua variabel terhadap environmental disclosure.

Environmental disclosure merupakan pengungkapan informasi terkait lingkungan yang dilakukan perusahaan. Salah satu faktor yang dapat mempengaruhi tingkat pengungkapan lingkungan perusahaan adalah environmental performance atau kinerja lingkungan yang telah dilakukan perusahaandan komposisi dewan komisaris yang ditunjukkan dengan banyaknya anggota komisaris independen di dalam keanggotaan dewan komisaris. Berdasarkan hasil pengujian secara simultan, Semakin tinggi prestasi kinerja lingkungan perusahaan dan semakin banyak anggota komisaris independen dalam satu perusahaan akan membuat perusahaan melakukan pengungkapan secara lebih terbuka dan transparan dalam hal pengungkapan lingkungannya.

\section{KESIMPULAN， IMPLIKASI DAN SARAN}

\section{Kesimpulan}

Kinerja lingkungan satu perusahaan memiliki pengaruh positif signifikan terhadap pengungkapan lingkungan yang dilakukan perusahaan ditahun 2011 2013. Hal ini menunjukkan perusahaan yang lebih peduli terhadap kondisi lingkungan hidup, yang ditunjukkan oleh tingginya peringkat PROPER yang diperoleh, cenderung lebih terbuka mengenai informasi lingkungan hidupnya kepada masyarakat luas. Prestasi yang dicapai ini tentu saja dimanfaatkan perusahaan sebagai satu cara untuk menunjukkan kepada masyarakat bahwa mereka peduli kepada lingkungan hidup dan berharap citra perusahaan di mata masyarakat meningkat serta timbulnya loyalitas konsumen yang peduli terhadap isu lingkungan hidup. 
Komposisi dewan komisaris dalam satu perusahaan yang di proksikan dengan komisaris independen, ternyata tidak berpengaruh secara signifikan terhadap pengungkapan lingkungan. Persentase komisaris independen perusahaan yang cukup tinggi pada tahun 2011 - 2013, tidak berdampak pada keputusan mengenai pengungkapan informasi lingkungan yang dibuat perusahaan. Hal ini menunjukkan peran komisaris independen yang tidak begitu kuat dalam mempengaruhi keputusan pengungkapan lingkungan yang dibuat perusahaan. Lemahnya peran komisaris independen dapat dipengaruhi oleh beberapa faktor, antara lain latar belakang pendidikan yang bukan dari bidang lingkungan hidup, adanya komisaris independen yang merangkap jabatan sebagai komisaris ataupun direktur di perusahaan yang berbeda, serta tidak adanya komisaris yang memiliki latar belakang pekerjaan dibidang lingkungan hidup.

Secara simultan, kinerja lingkungan dan komposisi dewan komisaris berpengaruh positif signifikan terhadap pengungkapan lingkungan. Pengungkapan lingkungan dari perusahaan merupakan hak bagi masyarakat untuk mengetahui lebih jauh mengenai informasi terkait lingkungan yang dilakukan perusahaan.
Perusahaan dengan prestasi lingkungan yang baik akan mengungkapkan informasi lingkungan tersebut kepada masyarakat luas sebagai salah satu cara mendapatkan legitimasi, ditambah lagi dengan banyaknya jumlah anggota komisaris independen yang mewakili kepentingan masyarakat ada di luar perusahaan, maka perusahaan akan semakin terdorong untuk melakukan pengungkapan lingkungan yang lebih terbuka dan transparan.

\section{Implikasi}

Sebagai suatu penelitian di bidang ekonomi, penelitian ini memiliki beberapa implikasi diantaranya adalah:

a. Bagi literatur, penelitian ini dapat dijadikan referensi dalam mempelajari bidang environmental disclosure apabila melakukan penelitian yang serupa.

b. Hasil penelitian ini dapat dijadikan bahan pertimbangan bagi pemerintah dalam penyusunan aturan mengenai standar baku environmental disclosure, agar terjadi keseragaman format antar perusahaan sehingga dapat dengan mudah diperbandingkan. Selain itu, pengawasan terhadap sumber daya manusia yang lebih ketat juga harus dilakukan pemerintah guna menghindari terjadinya tindak Jurnal IImiah Wahana Akuntansi 
pidana korupsi dalam penindakan kasus pengungkapan informasi lingkungan.

c. Hasil penelitian ini juga dapat menumbuhkan kesadaran perusahaan dalam memaksimalkan fungsi pengawasan yang dilakukan komisaris independen, terutama dalam kaitannya dengan environmental disclosure, dengan cara memilih anggota dewan komisaris yang akuntable dan profesional.

\section{Saran}

Untuk penelitian selanjutnya terdapat beberapa saran atas keterbatasan penelitian ini, antara lain:

a. Penelitian ini hanya mengambil sampel dalam kurun waktu 2011-2013, untuk penelitian selanjutnya dapat menambahkan tahun penelitian hingga 2014 untuk mendapatkan hasil penelitian yang lebih baru dan mendeskripsikan kondisi yang lebih aktual.

b. Dari hasil penelitian, masih terdapat faktor-faktor lain yang mampu menjelaskan environmental disclosure suatu perusahaan. Faktor lain yang dapat dimasukkan dalam penelitian selanjutnya adalah seperti faktor latar belakang pendidikan komisaris independen.

c. Menggunakan instrumen penelitian lain dalam mengukur variabel kinerja lingkungan, misalnya mengadopsi instrumen luar negeri sebagai pembanding, seperti environmental performance indikators dari World Bank atau International Organization for Standardization yang menetapkan ISO 14000. 
Abdi,

2014.

http://www.suarakendari.com/kolaka -merugi-triliunan-rupiah-akibat-

kerusakanlingkungan.html(diakses 1 Mei 2014, 16:17 WIB).

Bere, Sigiranus Marutho, 2014. http://regional.kompas.com/read/201 4/05/07/1738294/Protes.Limbah.Man gan.Belasan.Pastor.Datangi.DPRD.B elu?utm_source $=W P \& u t m \_$medium $=$ box\&utm_campaign $=$ Kknwp $($ diakses 15 Mei 2014, 01:44 WIB).

Clarkson, P.M., Michael dan Larelle, 2010. "Environmental Reporting and its Relation to Corporate Environmental Performance". University of Queensland, Brisbane: Australia.

Effendi, B., Lia dan Agus, 2011. "Pengaruh Dewan Komisaris terhadap Environmental Disclosure Pada Perusahaan Manufaktur yang Listing di BEI Tahun 2008-2011”. Univeritas Sultan Ageng Tirtayasa.

Gladia, Primadan dan Surya, 2013. "Pengaruh Environmental Performance terhadap Environmental Disclosure dan Hard EnvironmentalDisclosure

Perusahaan". Diponegoro Journal of Accounting.

Global Reporting Initiative, 2006. Pedoman Laporan Keberlanjutan.

Handayani, Ari Retno, 2010. "Pengaruh Environmental Performance terhadap Environmental Disclosure dan Economic Performance serta Environmental Disclosure terhadap Economic Performance". Universitas Diponegoro, Semarang.

\section{DAFTAR PUSTAKA}

Jurnal Ilmiah Wahana Akuntansi 
Harahap, Sofyan Syafri, 2011. "Teori Akuntansi Edisi Revisi 2011”. Rajawali Pers, Jakarta.

Harjito, D.A., 2012. "Dasar - Dasar Teori Keuangan”. Ekonisia: Yogyakarta.

Ikatan Akuntan Indonesia, Pernyataan Standar Akuntansi Keuangan No. 1 (Revisi 2009).

Ikhsan, Arfan, 2009. "Akuntansi Manajemen Lingkungan". Graha Ilmu: Yogyakarta.

Ikhsan, Arfan, 2008. "Akuntansi Lingkungan dan Pengungkapannya”. Graha Ilmu: Yogyakarta.

Keputusan Menteri Negara Lingkungan Hidup Republik Indonesia Nomor 35 Tahun 2012 Tentang Perubahan atas Keputusan Menteri Negara Lingkungan Hidup Nomor 295 Tahun 2011 Tentang Hasil Penilaian Peringkat Kinerja Perusahaan Dalam Pengelolaan Lingkungan Hidup (PROPER) Tahun 2010 - 2011.

Keputusan Menteri Negara Lingkungan Hidup Republik Indonesia Nomor 273 Tahun 2012 Tentang Hasil Penilaian Peringkat Kinerja Perusahaan Dalam Pengelolaan Lingkungan Hidup (PROPER) Tahun 2011 - 2012.

Keputusan Menteri Negara Lingkungan Hidup Republik Indonesia Nomor 349 Tahun 2013 tentang Hasil Penilaian Peringkat Kinerja Perusahaan Dalam Pengelolaan Lingkungan Hidup (PROPER) Tahun 2012 - 2013.
Kurniawan,

Riko, 2014. https://www.change.org/id/petisi/pak -sbyudhoyono-cabut-izinperusahaanpembakar-hutan-di-riau(diakses 15 Mei 2014, 01:44 WIB).

Sekretariat PROPER KLH, 2011. "Laporan Hasil Penilaian Program Penilaian Peringkat Kinerja Perusahaan Dalam Pengelolaan Lingkungan Hidup". Kementrian Lingkungan Hidup.

Suhardjanto, Djoko dan Novita, 2010. "Pengaruh Corporate Governance, Etnis, dan Latar Belakang Pendidikan Terhadap Environmental Disclosure: Studi Empiris Pada Perusahaan Listing di BEI". Jurnal Kinerja, volume 14.

Suwaldiman, 2009. "Kapita Selekta Akuntansi: Current Issues dalam Teori Akuntansi dan Akuntansi Manajemen." Ekonisia: Yogyakarta.

Tuwaijri, Christensen dan Hughes, 2003. "The Relation among Environmental Disclosure, Environmental Performance, and Economic Performance: A Simultaneous Equations Approach". University of Petroleum and Minerals.

Undang-Undang Republik Indonesia Nomor 32 Tahun 2009 Tentang Perlindungan Dan Pengelolaan Lingkungan Hidup.

Uwuigbe, U.N., Ben dan Akanbi, 2011. "The Effect of Board Size and Board Composition on Firms Corporate Environmental Disclosure: A Study of Selected Firms in Nigeria". ACTA Universitatis Danubus, Volume 7. 


\begin{tabular}{|r|l|l|}
\hline No & Kode Saham & \multicolumn{1}{|c|}{ Nama Perusahaan } \\
\hline 1 & AALI & Astra Agro Lestari \\
\hline 2 & ADRO & Adaro Energy \\
\hline 3 & ANTM & Aneka Tambang \\
\hline 4 & AMFG & Asahimas Flat Glass \\
\hline 5 & ASII & Astra International \\
\hline 6 & UNSP & Bakrie Sumatera Plantations \\
\hline 7 & BRAU & Berau Coal Energy \\
\hline 8 & FASW & Fajar Surya Wisesa \\
\hline 9 & HMSP & HM Sampoerna \\
\hline 10 & SMCB & Holcim Indonesia \\
\hline 11 & INKP & Indah Kiat Pulp \& Paper \\
\hline 12 & INTP & Indocement Tunggal Prakarsa \\
\hline 13 & ICBP & Indofood CBP Sukses \\
& & Makmur \\
\hline 14 & INDF & Indofood Sukses Makmur \\
\hline 15 & KLBF & Kalbe Farma \\
\hline 16 & KAEF & Kimia Farma \\
\hline 17 & LPCK & Lippo Cikarang \\
\hline 18 & MEDC & Medco Energi International \\
\hline 19 & SIMP & Salim Ivomas Pratama \\
\hline 20 & SGRO & Sampoerna Agro \\
\hline 21 & TINS & Timah (Persero) \\
\hline 22 & INRU & Toba Pulp Lestari \\
\hline 23 & UNIC & Unggul Indah Cahaya \\
\hline 24 & UNVR & Unilever Indonesia \\
\hline & & \\
\hline
\end{tabular}

\section{LAMPIRAN}

\section{DAFTAR PERUSAHAAN- PERUSAHAAN SAMPEL}

Sumber: Diolah oleh penulis (2014)

\section{DAFTAR INDIKATOR ENVIRONMENTAL DISCLOSURE MENURUT GRI G3}

INDIKATOR KINERJA LINGKUNGAN
\begin{tabular}{c|l|}
\multirow{4}{*}{ Aspek: } & $\begin{array}{l}\text { EN1 Penggunaan Bahan; } \\
\text { diperinci berdasarkan berat } \\
\text { atau volume }\end{array}$ \\
\cline { 2 - 2 } Material & $\begin{array}{l}\text { EN2 Persentase } \\
\text { Penggunaan Bahan Daur }\end{array}$ \\
\hline
\end{tabular}
Jurnal IImiah Wahana Akuntansi 


\begin{tabular}{|c|c|}
\hline \multicolumn{2}{|c|}{ INDIKATOR KINERJA LINGKUNGAN } \\
\hline & Ulang \\
\hline \multirow{6}{*}{$\begin{array}{l}\text { Aspek: } \\
\text { Energi }\end{array}$} & $\begin{array}{l}\text { EN3 Penggunaan Energi } \\
\text { Langsung dari Sumber } \\
\text { daya Energi Primer }\end{array}$ \\
\hline & $\begin{array}{l}\text { EN4 Pemakaian Energi } \\
\text { Tidak Langsung } \\
\text { berdasarkan Sumber } \\
\text { Primer }\end{array}$ \\
\hline & $\begin{array}{l}\text { EN5 Penghematan Energi } \\
\text { melalui Konservasi dan } \\
\text { Peningkatan Efisiensi }\end{array}$ \\
\hline & $\begin{array}{l}\text { EN6 Inisiatif untuk } \\
\text { mendapatkan produk dan } \\
\text { jasa berbasis energi efisien } \\
\text { atau energi yang dapat } \\
\text { diperbarui, serta } \\
\text { pengurangan persyaratan } \\
\text { kebutuhan energi sebagai } \\
\text { akibat dari inisiatif } \\
\text { tersebut. }\end{array}$ \\
\hline & $\begin{array}{l}\text { EN7 Inisiatif untuk } \\
\text { mengurangi konsumsi } \\
\text { energi tidak langsung dan } \\
\text { pengurangan yang dicapai }\end{array}$ \\
\hline & $\begin{array}{l}\text { EN8 Total pengambilan air } \\
\text { per sumber }\end{array}$ \\
\hline \multirow[t]{2}{*}{ Aspek Air } & $\begin{array}{l}\text { EN9 Sumber air yang } \\
\text { terpengaruh secara } \\
\text { signifikan akibat } \\
\text { pengambilan air }\end{array}$ \\
\hline & $\begin{array}{l}\text { EN10 Persentase dan total } \\
\text { volume air yang digunakan } \\
\text { kembali dan didaur ulang }\end{array}$ \\
\hline $\begin{array}{c}\text { Aspek } \\
\text { Biodiversitas } \\
\text { (Keanekaraga } \\
\text { man Hayati) }\end{array}$ & $\begin{array}{l}\text { EN11 Lokasi dan Ukuran } \\
\text { Tanah yang dimiliki, } \\
\text { disewa, dikelola oleh } \\
\text { organisasi pelapor yang } \\
\text { berlokasi di dalam, atau } \\
\text { yang berdekatan dengan } \\
\text { daerah yang diproteksi } \\
\text { (dilindungi) atau daerah- } \\
\text { daerah yang memiliki } \\
\text { nilai keanekaragaman } \\
\text { hayati yang tinggi di luar } \\
\text { daerah yang diproteksi. }\end{array}$ \\
\hline
\end{tabular}

\section{INDIKATOR KINERJA LINGKUNGAN}

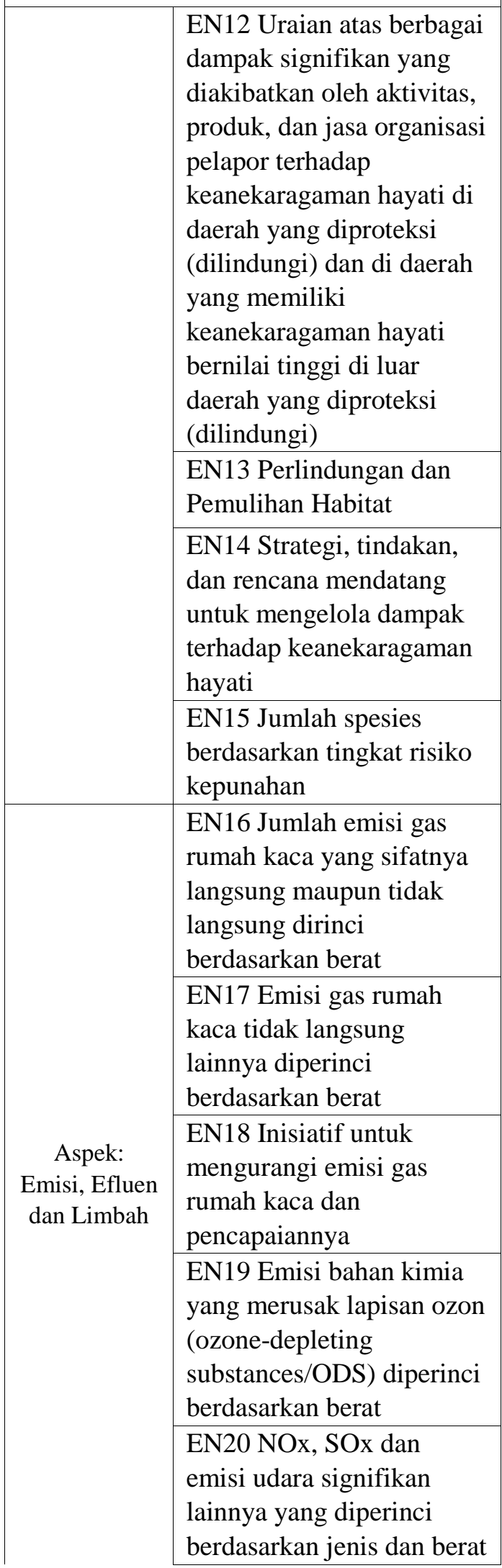

Jurnal IImiah Wahana Akuntansi 


\begin{tabular}{|c|c|}
\hline \multicolumn{2}{|c|}{ INDIKATOR KINERJA LINGKUNGAN } \\
\hline & $\begin{array}{l}\text { EN21 Jumlah buangan air } \\
\text { menurut kualitas dan } \\
\text { tujuan }\end{array}$ \\
\hline & $\begin{array}{l}\text { EN22 Jumlah berat limbah } \\
\text { menurut jenis dan metode } \\
\text { pembuangan }\end{array}$ \\
\hline & $\begin{array}{l}\text { EN23 Jumlah dan volume } \\
\text { tumpahan yang signifikan }\end{array}$ \\
\hline & $\begin{array}{l}\text { EN24 Berat limbah yang } \\
\text { diangkut, diimpor, } \\
\text { diekspor, atau diolah yang } \\
\text { dianggap berbahaya }\end{array}$ \\
\hline & $\begin{array}{l}\text { EN25 Identitas, ukuran, } \\
\text { status proteksi dan nilai } \\
\text { keanekaragaman hayati } \\
\text { badan air serta habitat } \\
\text { terkait yang secara } \\
\text { signifikan dipengaruhi } \\
\text { oleh pembuangan dan } \\
\text { limpasan air organisasi } \\
\text { pelapor. }\end{array}$ \\
\hline \multirow[t]{2}{*}{$\begin{array}{c}\text { Aspek: } \\
\text { Produk dan } \\
\text { Jasa }\end{array}$} & $\begin{array}{l}\text { EN26 Inisiatif untuk } \\
\text { mengurangi dampak } \\
\text { lingkungan produk dan } \\
\text { jasa dan sejauh mana } \\
\text { dampak pengurangan } \\
\text { tersebut. }\end{array}$ \\
\hline & $\begin{array}{l}\text { EN27 Persentase produk } \\
\text { terjual dan bahan } \\
\text { kemasannya yang ditarik } \\
\text { menurut kategori. }\end{array}$ \\
\hline $\begin{array}{l}\text { Aspek: } \\
\text { Kepatuhan }\end{array}$ & $\begin{array}{l}\text { EN28 Nilai Moneter } \\
\text { Denda yang signifikan dan } \\
\text { jumlah sanksi non - } \\
\text { moneter atas pelanggaran } \\
\text { terhadap hukum dan } \\
\text { regulasi lingkungan. }\end{array}$ \\
\hline $\begin{array}{l}\text { Aspek: } \\
\text { Pengangkutan } \\
\text { /Transportasi }\end{array}$ & $\begin{array}{l}\text { EN29 Dampak lingkungan } \\
\text { yang signifikan akibat } \\
\text { pemindahan produk dan } \\
\text { barang-barang lain serta } \\
\text { material yang digunakan } \\
\text { untuk operasi perusahaan, } \\
\text { dan tenaga kerja yang } \\
\text { memindahkan. }\end{array}$ \\
\hline
\end{tabular}

INDIKATOR KINERJA LINGKUNGAN

\begin{tabular}{|c|l|}
\hline $\begin{array}{c}\text { Aspek: } \\
\text { Menyeluruh }\end{array}$ & $\begin{array}{l}\text { EN30 Jumlah pengeluaran } \\
\text { untuk proteksi dan } \\
\text { investasi lingkungan } \\
\text { menurut jenis. }\end{array}$ \\
\hline
\end{tabular}

Sumber: Pedoman Laporan Keberlanjutan GRI G3 (2006) 